\title{
A panel of monoclonal antibodies to ovine placental lactogen
}

\author{
I A Forsyth, A Hutchings and G W Butcher \\ Molecular Immunology Programme and Monoclonal Antibody Unit, The Babraham Institute, Babraham, Cambridge CB2 4AT, UK \\ (Requests for offprints should be addressed to I A Forsyth)
}

\begin{abstract}
A panel of 11 rat monoclonal antibodies (mAbs) has been raised to ovine placental lactogen (PL). By competitive enzyme-linked immunoabsorbent assay (ELISA), confirmed by two-site ELISA, the antibodies were shown to recognize six antigenic determinants on the ovine PL molecule, two of which overlap. One antigenic determinant (designated 1) was shared by other members of the prolactin/growth hormone (GH)/PL family in ruminants, humans and rodents. The binding of ${ }^{125}$ I-labelled ovine
\end{abstract}

PL to crude receptor preparations from sheep liver (somatotrophic) or rabbit mammary gland (lactogenic) was inhibited by $\mathrm{mAbs}$ recognizing antigenic determinants $2-6$. Both types of receptor preparation were affected similarly. In the local in vivo pigeon crop sac assay, mAbs directed against determinants 3 and 6 enhanced the biological activity of ovine PL.

Journal of Endocrinology (2000) 165, 435-442

\section{Introduction}

Placental lactogens are a group of polypeptide hormones which are structurally related to prolactin and GH. They have evolved more than once, from the $\mathrm{GH}$ gene in primates (Walker et al. 1991) and from the prolactin gene in rodents and ruminants (see Forsyth 1994). Ovine placental lactogen (PL) is a $22 \mathrm{kDa}$ protein, synthesized by trophoectoderm binucleate cells in the cotyledonary placenta of sheep (Wooding et al. 1992), that reaches both the maternal and fetal circulations (Chan et al. 1978). Its physiological role in pregnant ewes and their fetuses is still poorly understood. There are potentially three receptor types through which it may act (see Sakal et al. 1997), the prolactin receptor, the $\mathrm{GH}$ receptor and a specific PL receptor suggested to exist, on the basis of affinity binding studies, mainly in fetal tissues (Freemark \& Comer 1989) and also in the sheep endometrium (Galosy et al. 1991).

To assist work on the biological role, the structureactivity relationships and the antigenic determinants of ovine PL, we have made rat monoclonal antibodies against the purified hormone and now report on their preparation and preliminary characterization.

\section{Materials and methods}

\section{Materials}

Ovine PL was purified and characterized as described by Colosi et al. (1989). It was labelled with either $\mathrm{Na}^{125} \mathrm{I}$ (Amersham International, Amersham, Bucks, UK) by the iodogen method (Salacinski et al. 1981) or biotin (N-hydroxysuccinimidobiotin, Calbiochem, Beeston, Nottingham, UK) by mixing antibody (1 $\mathrm{mg}$ in $1 \mathrm{ml}$ phosphate buffered saline, PBS, $\mathrm{pH} 7$ ) with biotin (1 mg in $40 \mu \mathrm{l}$ dimethylsulphoxide), stirring for $1 \mathrm{~h}$ at room temperature and dialysing.

\section{Immunization}

Four male rats of the F344 strain were injected with purified ovine PL (oPL, $100 \mu \mathrm{g})$ in Freund's adjuvant. Complete adjuvant was used for the first of three injections, given by i.m. and/or s.c. routes at 1-2 month intervals. A small blood sample was taken from the tail vein and tested by radioimmunoassay (Thordarson et al. 1987) for level of humoral immunity. Two rats showing the highest antibody titre ( $>40 \%$ labelled oPL bound at 1:1200 dilution, $\mathrm{v} / \mathrm{v}$ ) were given $100 \mu \mathrm{g}$ ovine PL in saline i.v. and killed 3 days later by exposure to rising concentrations of $\mathrm{CO}_{2}$.

\section{Generation of monoclonal antibodies}

Rat spleen cells and rat myeloma cell line Y3Ag1·2.3 (Galfrè et al. 1979) or IR983F (Bazin 1982, Table 1) were fused and hybridomas obtained after HAT (hypoxanthine, aminopterin and thymidine) selection using standard methods (Galfrè \& Milstein 1981). Culture media were tested for antibody using either radioimmunoassay (Thordarson et al. 1987) or enzyme-linked immunoabsorbent assay (ELISA, see below). Positive hybridomas were grown on and cloned on agar. In some cases, ascitic 
fluids were generated in (LOU/c x F344)F1 rats, to obtain larger quantities of particular antibodies for purification and biotinylation.

\section{Cross-reactivity and antigenic mapping}

A solid-phase ELISA method was used to obtain information on binding of antibodies to oPL and to other members of the prolactin/GH gene family. A competitive ELISA gave preliminary data on antigenic determinants on ovine PL. To confirm the results on antigenic determinants, a two-site ELISA method was used.

Solid-phase ELISA Ninety-six-well plates (Dynatech, Billingshurst, Sussex) were coated overnight at $4{ }^{\circ} \mathrm{C}$ with ovine PL (1 $\mu \mathrm{g} /$ well) in $100 \mu \mathrm{l}$ PBS (pH 7) and blocked for $2 \mathrm{~h}$ at $4{ }^{\circ} \mathrm{C}$ with $10 \%$ fetal calf serum (FCS) in PBS. Other purified antigens tested at $1 \mu \mathrm{g} /$ well for cross-reactivity were: ovine (NIH-P-S9) and bovine (NIH-P-B4) prolactin, ovine (NIH-GH-S9) and bovine (NIH-GH-B2) GH, human PL (National Hormone and Pituitary Program, Bethesda, MD, USA), bovine PL (USDA-bPL-I-1, United States Department of Agriculture, Beltsville, MD, USA), human GH (Dr A Stockell-Hartree, University of Cambridge, UK), mouse PL-I and -II (Dr G Thordarson, University of California, Santa Cruz, CA, USA) and rat PL-I and -II (Dr R Shiu, University of Manitoba, Canada). Unlabelled antibody (supernatant from hybridoma cultures at dilutions from neat to $1: 64, \sim 5 \mathrm{mg} / \mathrm{l}$ to $80 \mu \mathrm{g} / \mathrm{lgG}$, or ascites at dilutions from $1: 100$ to 1 : $218700, \sim 10 \mathrm{mg} / 1$ to $5 \mu \mathrm{g} / \mathrm{l})$ was added and incubated for $2 \mathrm{~h}$ at $4{ }^{\circ} \mathrm{C}$. The plates were washed 3 times in tap water, incubated for $1.5 \mathrm{~h}$ at room temperature with horseradish-peroxidase conjugated anti-rat $\operatorname{IgG}$ (Dako, Ely, Cambs), washed once with Tween $20(0 \cdot 05 \mathrm{~g} / \mathrm{l})$ and 10 times with tap water, developed using 3,3',5,5'tetramethylbenzidine (Pierce and Warriner (UK) Ltd, Chester, UK) and read in a microphotometer. $\mathrm{mAb}$ EM1/21.9 directed against an irrelevant nematode antigen was used as a negative control; binding above mean +1S.D. $(n=11)$ was regarded as positive.

Competitive ELISA The method was as described for the solid-phase ELISA, except that biotin-labelled antibody (25-100 ng/well in $50 \mu \mathrm{lBS}, \mathrm{pH} 7)$ was added to oPL-coated 96-well plates together with dilutions of unlabelled antibody. Incubation was for $2 \mathrm{~h}$ at $4{ }^{\circ} \mathrm{C}$. The plates were washed twice in tap water before incubation for $30 \mathrm{~min}$ at $37^{\circ} \mathrm{C}$ with streptavidin-horseradish peroxidase complex (Amersham International, diluted 1:500 in 10\% FCS in PBS). Plates were washed twice with Tween $20(1 \mathrm{~g} / 1$ in PBS $)$ and 10 times in tap water. They were developed using 3,3',5,5'-tetramethylbenzidine (Pierce and Warriner (UK) Ltd, Chester, UK) and read in a microphotometer.
Two-site ELISA Using 96-well plates, unlabelled antibody was bound to each well by adding $100 \mu \mathrm{l}$ of the first antibody solution $(10 \mu \mathrm{g} / \mathrm{ml})$ and incubating for $2 \mathrm{~h}$ at room temperature. The wells were washed twice with tap water, blocked for $2 \mathrm{~h}$ at $4{ }^{\circ} \mathrm{C}$ with 10\% FCS in PBS (pH 7) and washed again. Ovine PL ( $0 \cdot 1,0 \cdot 5,1,5,10,15$ and $20 \mu \mathrm{g}$ in $100 \mu \mathrm{l}$ blocking buffer) was added and the plates incubated for $2 \mathrm{~h}$ at room temperature. The second antibody $(1 \mu \mathrm{g} / \mathrm{ml})$, labelled with biotin and diluted with blocking buffer, was then added and plates were incubated for $2 \mathrm{~h}$ at room temperature. They were washed, developed and read as described for the competitive ELISA. The second, biotin-labelled, antibody will bind to ovine PL only if it recognizes an antigenic determinant not overlapping with that recognized by the first antibody bound to the microtitre plate.

\section{Tissue binding studies}

The effect of the mAbs on interaction of ovine PL with tissue receptors was investigated by minor modification of the method of Cadman et al. (1982). Microsomes were prepared by homogenization and differential centrifugation (Winder et al. 1993) from the mammary glands of bromocriptine-treated New Zealand White rabbits in early lactation and the livers of Poll-Dorset ewes and were freeze dried (Parke \& Forsyth 1975). Displacement studies using unlabelled ovine PL, ovine prolactin (NIH-P-S-12, 35 i.u. $/ \mathrm{mg}$ ) and bovine $\mathrm{GH}$ (NIH-B-GH-2, 1.5 i.u./mg) confirmed that rabbit mammary gland contains predominantly lactogenic receptors (displaced by prolactin and ovine PL, but not by bovine GH, Kelly et al. 1976), while sheep liver contains mainly somatotrophic receptors (displaced by bovine GH and ovine PL, but not by prolactin, Brier et al. 1994). Doubling dilutions of monoclonal antibody $(100 \mu \mathrm{l})$, assay buffer $(25 \mathrm{mmol}$ Tris $-\mathrm{HCl} / \mathrm{l}, \mathrm{pH}$ $7 \cdot 4,10 \mathrm{mmol} \mathrm{CaCl}_{2} / \mathrm{l}, 0 \cdot 1 \%(\mathrm{w} / \mathrm{v})$ bovine serum albumin, $200 \mu \mathrm{l})$ and ${ }^{125}$ I-labelled oPL $(100 \mu \mathrm{l}, 20000$ c.p.m.) were incubated at $4{ }^{\circ} \mathrm{C}$ for $48 \mathrm{~h}$. Microsomes $(1 \mathrm{mg}$ in $100 \mu \mathrm{l}$ assay buffer) were added and incubation continued overnight at room temperature. Ice-cold assay buffer $(1 \mathrm{ml})$ was added and tubes spun at $1820 \mathrm{~g}$ for $30 \mathrm{~min}$ at $4{ }^{\circ} \mathrm{C}$. Radioactivity in the pellet was counted. Parallel determinations of antibody titre were carried out by adding buffer only instead of microsomes after $48 \mathrm{~h}$ and, following overnight incubation, separating bound and free label using a second antibody (donkey anti-mouse $\operatorname{IgG}$, Cambridge Medical Diagnostics, Billerica, MA, USA).

\section{Bioassay}

The effect of $\mathrm{mAbs}$ on the biological activity of ovine PL was tested using dilutions of ascitic fluids in the pigeon crop sac assay (Nicoll 1967). Birds were allocated to treatment at random and received a single injection $(0 \cdot 1 \mathrm{ml}$ i.d.) of ovine PL ( 3 or $5 \mu \mathrm{g}$ in saline or in control 
Table 1 Designation and isotype of monoclonal antibodies to ovine placental lactogen

\begin{tabular}{|c|c|c|c|}
\hline \multirow[b]{2}{*}{$\mathrm{mAb}$} & \multirow[t]{2}{*}{ Myeloma } & \multirow[t]{2}{*}{ Fusion number* } & \multirow[t]{2}{*}{ Isotype } \\
\hline & & & \\
\hline MAC 193 & IR983F & 1 & $\operatorname{lgG} 2 a$ \\
\hline MAC 215 & $\mathrm{Y} 3$ & 2 & $\operatorname{lgG} 2 b$ \\
\hline MAC 216 & Y3 & 2 & $\lg G 2 a$ \\
\hline MAC 217 & Y3 & 2 & $\lg G 2 a$ \\
\hline MAC 218 & Y3 & 2 & $\operatorname{lgG} 2 b$ \\
\hline MAC 219 & IR983F & 3 & $\lg G 2 a$ \\
\hline MAC 220 & IR983F & 3 & $\lg G 2 b$ \\
\hline MAC 221 & IR983F & 3 & $\operatorname{lgG} 1$ \\
\hline MAC 222 & IR983F & 3 & $\operatorname{lgG} 2 a$ \\
\hline MAC 223 & IR983F & 3 & $\lg G 2 b$ \\
\hline MAC 224 & IR983F & 3 & $\operatorname{lgG} 2 a$ \\
\hline
\end{tabular}

*Fusions 2 and 3 used the two halves of the same spleen.

monoclonal) over one crop sac and the same dose of ovine $\mathrm{PL}$ plus $\mathrm{mAb}$ to ovine PL over the contralateral crop. Sites could be regarded as independent, as in excess of $20 \mu \mathrm{g}$ ovine PL would be required to affect one crop if injected over the other (Nicoll 1967). Ovine PL and mAb were pre-incubated for $60 \mathrm{~min}$ before injection. Dilutions of ascitic fluid were calculated by reference to antibody titre (see Aston et al. 1986). The pigeons were killed by cervical dislocation $48 \mathrm{~h}$ later and the wet weight of crop mucosa, removed from a standard $4 \mathrm{~cm}$ diameter area, was determined. The $\mathrm{mAb}$ used as control was directed against nitrate reductase of spinach (AFRC MAC 77, Notton et al. 1984). The statistical significance of differences was tested using Student's t-test, either unpaired (between birds) or paired (within birds).

\section{Results}

\section{Antigenic mapping of ovine PL by ELISA methods}

The $11 \mathrm{mAbs}$ generated and their IgG class and subclass are shown in Table 1. Competitive ELISA (Fig. 1 and Table 2) indicates that the 11 antibodies recognize six antigenic determinants (summarized in Fig. 2). Determinants 4 and 5 are suggested as partially overlapping on the basis of non-reciprocal competition between MAC 222 and 224 and the ability of MAC 215 to compete with both (Table 2). Using MAC 193, 218, 220, 221, 222, 223 and 224 in the two-site ELISA (Fig. 3a, b), these conclusions were confirmed. MAC 218 and MAC 220 each interfered with the ability of the other to bind, as did MAC 224 with MAC 222.

MAC 223 (determinant 1) bound to all members of the prolactin/GH/PL family tested with the exception of mouse PLII (Fig. 4a, b). Cross-reactivity was also detected of MAC 217 (determinant 1) on bovine PL, ovine and bovine prolactin (Fig. 4a), ovine, bovine and human $\mathrm{GH}$
Table 2 Competitive ELISA assay: ability of unlabelled monoclonal antibody ( $1: 4$ dilution, $\sim 1 \cdot 25 \mathrm{mg} / \mathrm{l})$ to compete with biotin-labelled monoclonal antibody for binding sites on ovine PL ( $1 \mu \mathrm{g} /$ well). Self-competition is underlined and competing antibodies are shown in bold type. Biotinylation of MAC 224 partially interfered with ability to bind ovine PL. Values are optical density at $490 \mathrm{~nm}$

\begin{tabular}{|c|c|c|c|c|c|c|}
\hline \multirow[b]{2}{*}{$\begin{array}{l}\text { Unlabelled } \\
\text { mAb }\end{array}$} & \multicolumn{6}{|c|}{ Labelled mAb } \\
\hline & 193 & 220 & 221 & 222 & 223 & 224 \\
\hline 193 & $0 \cdot 19$ & $0 \cdot 91$ & 1.06 & 0.63 & $0 \cdot 74$ & $0 \cdot 44$ \\
\hline 215 & $\overline{0.72}$ & $1 \cdot 18$ & 1.05 & $0 \cdot 27$ & 0.96 & $0 \cdot 33$ \\
\hline 216 & $1 \cdot 11$ & $1 \cdot 00$ & $1 \cdot 24$ & $1 \cdot 07$ & $0 \cdot 22$ & 0.74 \\
\hline 217 & 1.09 & 1.06 & $1 \cdot 25$ & $1 \cdot 00$ & $0 \cdot 21$ & 0.83 \\
\hline 218 & 0.74 & $0 \cdot 19$ & $1 \cdot 31$ & $0 \cdot 86$ & 0.53 & 0.62 \\
\hline 219 & $1 \cdot 00$ & $1 \cdot 02$ & $1 \cdot 35$ & $1 \cdot 01$ & $0 \cdot 31$ & 0.78 \\
\hline 220 & 0.66 & $0 \cdot 20$ & $1 \cdot 28$ & $1 \cdot 49$ & 0.60 & 0.56 \\
\hline 221 & 0.79 & $1 \cdot 39$ & $0 \cdot 21$ & $0 \cdot 85$ & 0.64 & 0.68 \\
\hline 222 & $0 \cdot 82$ & $1 \cdot 27$ & $\overline{1 \cdot 25}$ & $0 \cdot 28$ & $1 \cdot 04$ & 0.62 \\
\hline 223 & $0 \cdot 88$ & 1.06 & $1 \cdot 24$ & $1 \cdot 07$ & $0 \cdot 18$ & 0.75 \\
\hline 224 & 0.91 & $1 \cdot 35$ & $1 \cdot 14$ & $0 \cdot 29$ & $\overline{0 \cdot 72}$ & $0 \cdot 24$ \\
\hline
\end{tabular}

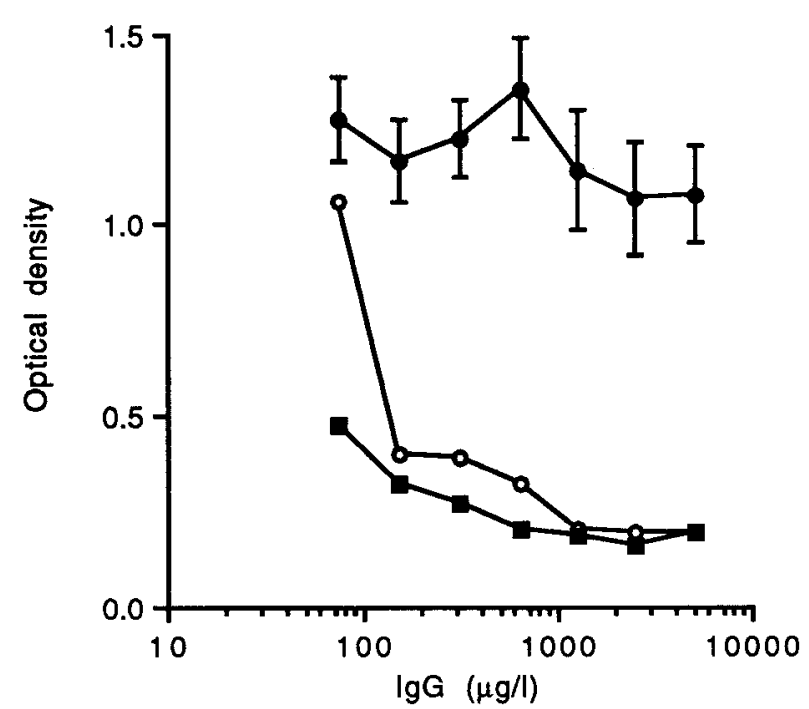

Figure 1 Competitive ELISA: ability of dilutions of unlabelled monoclonal antibodies to compete with biotin-labelled MAC 220 for binding sites on ovine PL $(1 \mu \mathrm{g} /$ well). Values for nine noncompeting mAbs (MAC 193, 215, 216, 217, 219, 221, 222, 223 and 224) are shown as means \pm S.D. $(\bigcirc) ; 220(\bigcirc) ; 218(\mathbf{\square})$.

(Fig. 4b), and of MAC 219 (determinant 1) on bovine PL, ovine and bovine prolactin (Fig. 4a). No other mAbs showed cross-reactivity (defined as binding not significantly greater than that shown by the negative control).

Influence of monoclonal antibodies on binding of ovine PL to microsomes prepared from rabbit mammary gland or sheep liver

The mAbs were tested for their effect on interaction between ${ }^{125} \mathrm{I}$-labelled ovine PL and tissue binding sites. 


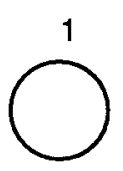

223

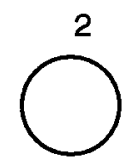

220

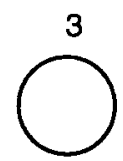

193

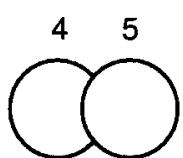

224222

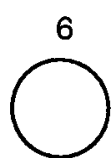

221
Site

Defining MAC

$\begin{array}{llll}216 & 218 & 215 & \text { Other MACs } \\ 217 & & & \\ 219 & & \end{array}$

Figure 2 Schematic diagram of antigenic determinants 1-6 on ovine PL recognized by rat monoclonal antibodies. Non-intersecting circles represent non-overlapping determinants. Determinants 4 and 5 are presented as partially overlapping on the basis of ELISA results (see text). Determinant 1 is shared with other ruminant and human prolactins, GHs and PLs.

The specific binding of ${ }^{125} \mathrm{I}$-oPL was $40 \cdot 8 \%$ to heterologous rabbit mammary gland microsomes (lactogenic) and $29 \cdot 2 \%$ to homologous sheep liver microsomes (somatotrophic). In all cases, the effect of $\mathrm{mAbs}$ on binding to rabbit mammary gland receptors and to sheep liver receptors was similar (Fig. 5). Seven monoclonal antibodies, MAC 218 and 220 (determinant 2), 193 (determinant 3), 224 (determinant 4), 222 (determinant 5), 215 (determinant 4/5) and 221 (determinant 6), inhibited the binding of ovine PL (Fig. 5a, b). Potency varied and MAC 224, 222 and 215, directed against the overlapping determinants 4 and 5 , were effective only when present at high concentration (Fig. 5b). In some cases (MAC 218, 193 and 221) binding recovered at higher $\mathrm{mAb}$ concentrations (Fig. 5a). Four antibodies (MAC 223, 216, 217 and 219), all directed against antigenic determinant 1 , had little inhibitory effect on oPL binding. MAC 223 enhanced binding at higher concentrations (Fig. 5c).

\section{Effect on biological activity}

The wet weight of crop sac mucosa from a $4 \mathrm{~cm}$ diameter site was $10.4 \pm 1.9 \mathrm{mg}$ (mean \pm s.E.M., $n=6$ ). After a single injection of ovine PL, the weight was $11.1 \pm 0.7 \mathrm{mg}$ ( $3 \mu \mathrm{g}$ ovine PL, $n=16, P>0 \cdot 1)$ or $17 \cdot 9 \pm 1 \cdot 0 \mathrm{mg}(5 \mu \mathrm{g}$ ovine PL, $n=28, P<0 \cdot 001)$. $\mathrm{mAb}$ to spinach nitrate reductase (MAC 77) had no effect on the response to ovine PL; crop weights in response to $5 \mu \mathrm{g}$ ovine PL combined with 1:500 and 1:4000 dilutions of MAC 77 were, respectively, $18 \cdot 2 \pm 2 \cdot 8 \mathrm{mg}(n=8, \quad P>0 \cdot 1)$ and $21 \cdot 0 \pm 2 \cdot 8 \mathrm{mg}(n=8, P>0 \cdot 1)$.

Effect on biological activity (Table 3) was tested using $\mathrm{mAbs}$ recognizing each of the six antigenic determinants (Fig. 2). At the dose used (2000 x ABT 50, where one ABT 50 is the dilution (titre) of $\mathrm{mAb}$ binding $50 \%$ of ${ }^{125}$ I-labelled oPL in a liquid phase), none of the ovine PL mAbs inhibited biological activity. Enhancement was seen with MAC 193 (determinant 3, Table 3) and MAC 221 (determinant 6).

\section{Discussion}

Competitive and two-site ELISA assays indicate that the 11 rat monoclonal antibodies raised against ovine PL recognize six antigenic sites. Mouse mAbs have been prepared which recognize four distinct epitopes on bovine GH (Aston et al. 1987, Krivi \& Rowold 1986). Human $\mathrm{GH}$ exibits at least ten epitopes, grouped into five antigenic regions, of which at least one is shared with human PL and one is not (Strasburger et al. 1989). As analogues of ovine PL become available, further analysis of its antigenic surface will be possible. One of the determinants on ovine PL (designated 1) was shared with other members of the prolactin/GH gene family and appears to be a major determinant, recognized by four of the $11 \mathrm{mAbs}$. On the basis of in vitro binding studies, this determinant did not appear to be involved in binding of ovine PL to receptors on rabbit mammary gland (lactogenic) or sheep liver (somatogenic); mAbs directed against the other five determinants all interfered in the binding of ${ }^{125}$ I-labelled ovine PL to receptors in vitro, but did not distinguish between heterologous (rabbit) lactogenic and homologous (sheep) somatogenic receptors.

Ligand-induced dimerization is a frequent mechanism to initiate signal transduction. A two-site model of sequential receptor homodimerization was developed by studying the interaction of human $\mathrm{GH}$ with the extracellular domain (ECD) of the human GH receptor (see Wells 1996). In this model, the hormone binds the first receptor through its binding site 1 and then a second receptor through binding site 2 . There is also a substantial receptorreceptor interface. The model is believed to apply to other helix-bundle peptides.

Consistent with this model, ovine PL forms 1:2 complexes with heterologous (rabbit and rat) prolactin receptor ECD and with heterologous (human) GH receptor ECD (Sakal et al. 1997). With bovine prolactin ECD (Sakal et al. 1997), a 1:2 complex is observed only transiently, because 
(a)

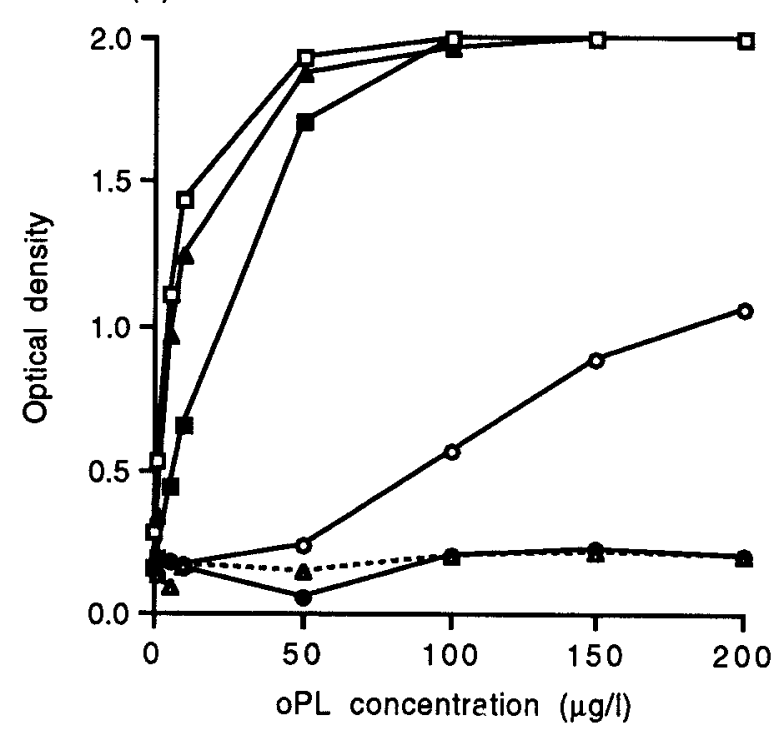

(b)

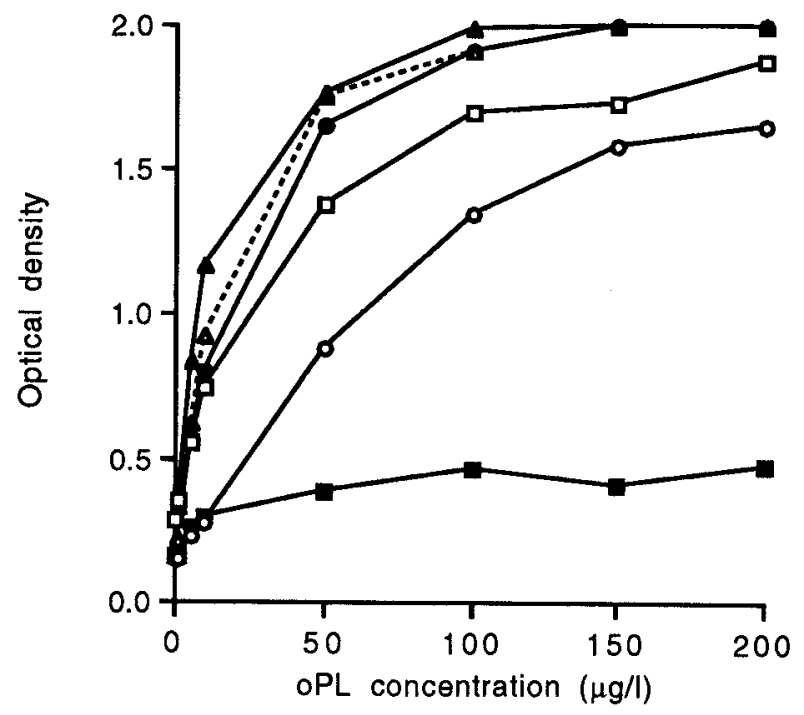

Figure 3 Two-site ELISA: ovine PL $(0-200 \mu \mathrm{g} / \mathrm{l})$ captured by unlabelled monoclonal antibody $(10 \mathrm{mg} / \mathrm{l})$ absorbed onto plastic (a) MAC 220; (b) MAC 224. Biotin-labelled MAC 193 (○), $218(\bullet), 220(\triangle), 221(\Delta), 222(\square)$ and $223(\square)$ bind only if recognizing a non-overlapping determinant.

of rapid dissociation to 1:1 complexes, associated with high $k_{\text {off }}$ constants (Gertler et al. 1996). By contrast, recent evidence (Herman et al. 1999) suggests ruminant PLs may be unable to homodimerize ruminant $\mathrm{GH}$ receptors, binding only through site 1 , and their status as growth hormone agonists in ruminants remains unclear (see also Staten et al. 1993).

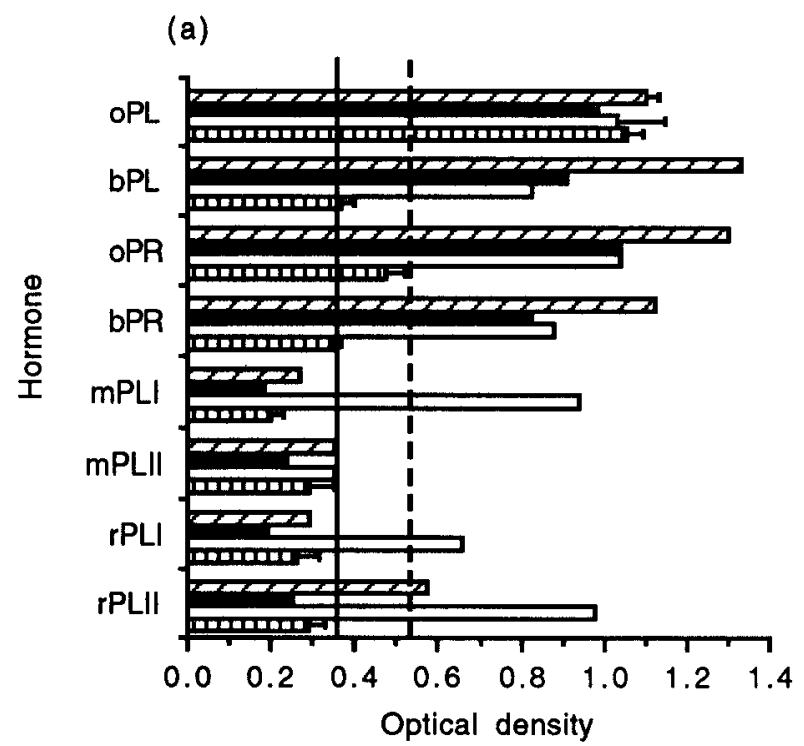

(b)

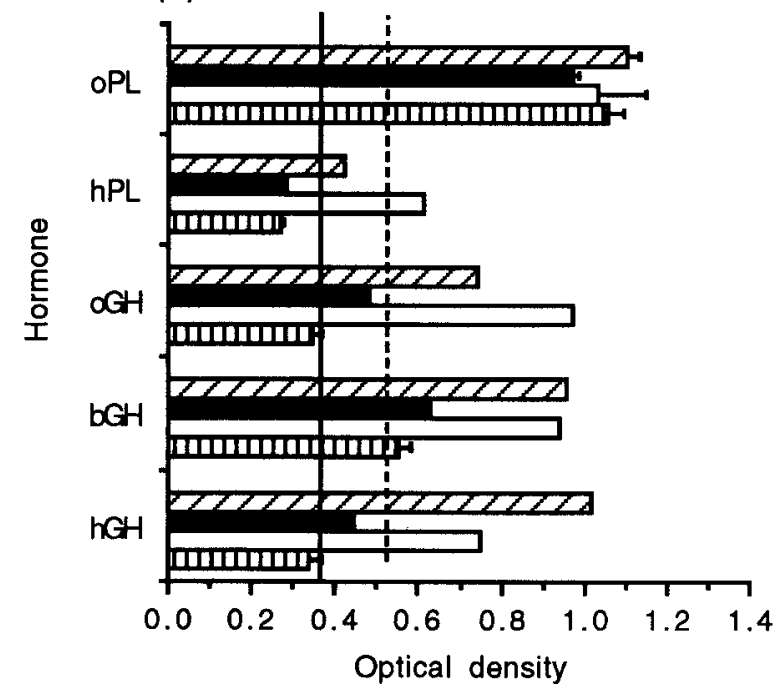

Figure 4 Solid phase ELISA: binding of MAC 217 (hatched bars), 219 (closed bars) and 223 (open bars) to hormones absorbed onto plastic. The hormones tested were (a) PL and prolactin (PR) and (b) PL and GH of ovine (o), bovine (b), human (h), mouse (m) and rat (r) origin (see Methods for full details: values shown are for undiluted culture supernatants, $\sim 5 \mathrm{mg} / \mathrm{l}$ specific $\operatorname{lgG}$ ). Values for the eight monoclonal antibodies showing binding only to oPL (MAC 193, 215, 216, 218, 220, 221, 222 and 224) are shown (means \pm S.E.M.) as vertically striped bars. The vertical lines are mean (continuous) and mean +1S.D. ( $n=11$, dotted) for the binding of a control monoclonal antibody (EM1/21.9). For MAC 217, 219 and 223 , binding to oPL is mean \pm S.E.M. $(n=4$ experiments) and means of closely agreeing duplicates for the other hormones.

The effect of $\mathrm{mAbs}$ on binding of ovine PL was the same for sheep liver microsomes and rabbit mammary gland microsomes, suggesting, therefore, that the binding 

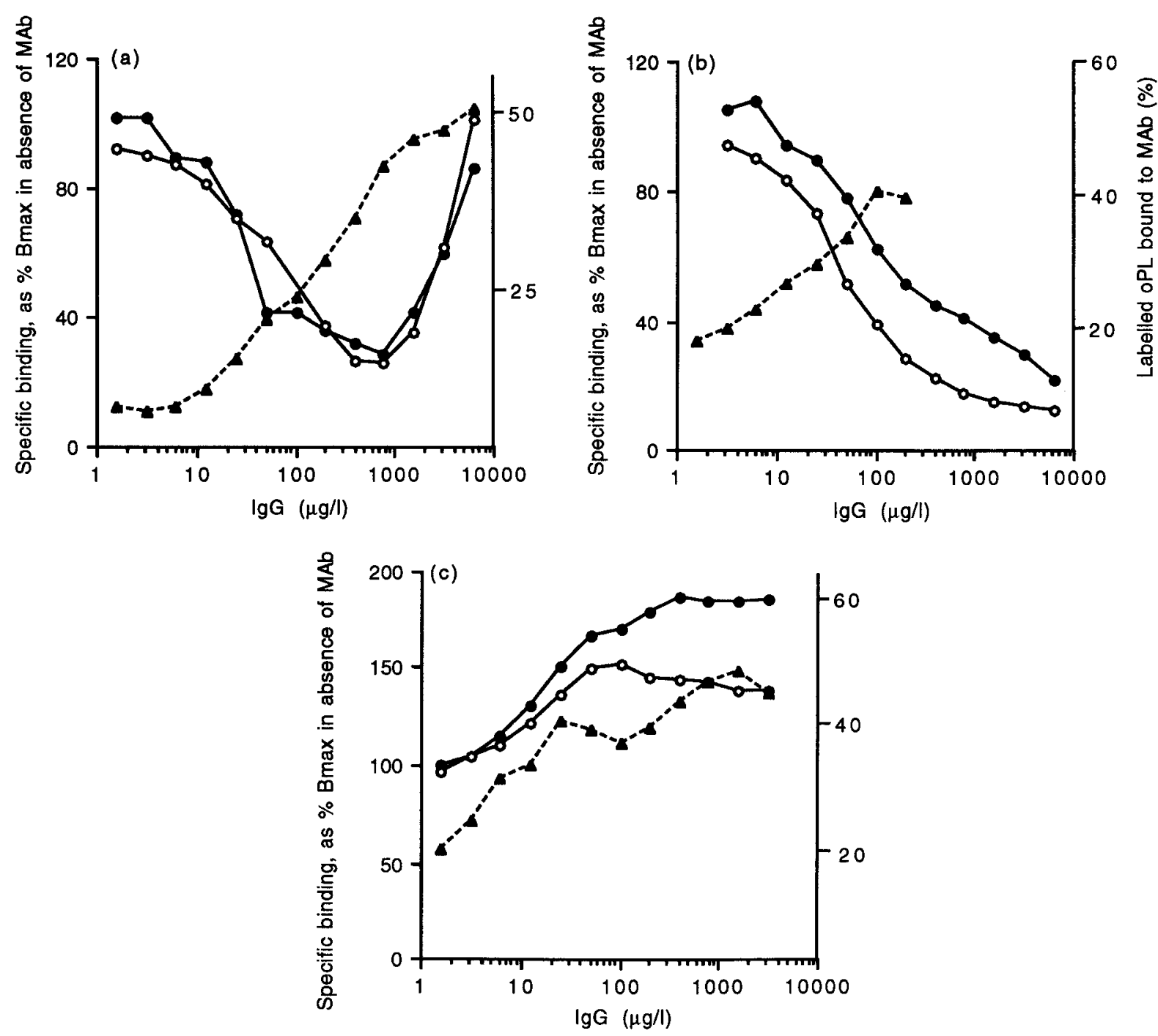

Figure 5 Effect of monoclonal antibodies raised against purified ovine PL on the binding of ${ }^{125}$ I-labelled ovine PL to microsomes prepared from rabbit mammary gland or sheep liver. ${ }^{125}$ I-labelled ovine PL was pre-incubated with dilutions of the monoclonal antibodies for $48 \mathrm{~h}$. Buffer $(\boldsymbol{\Delta})$, microsomes prepared from rabbit mammary gland $(\mathbf{O})$ or sheep liver $(\bigcirc)$ were then added and incubation continued for a further $24 \mathrm{~h}$. Binding was determined as described in the Methods. Each value is the mean of duplicate observations in one assay and all assays were replicated. (a) MAC 218; (b) MAC 224; (c) MAC 223.

assays measure site 1 interaction. If receptor binding is sequential, this would indeed be expected; subsequent site 2 binding would be reflected in percentage specific binding only if it resulted in stabilization and reduced dissociation of the hormone-receptor complex. Effect of mAbs on ability of hormone to bind to receptor may involve (i) binding to a region on the hormone making contact with receptor; (ii) binding close to a region on the hormone making contact with receptor and causing steric hindrance; (iii) binding to a region distinct from that making contact with receptor, affecting hormone conformation and changing affinity for the receptor. Each of these mechanisms could provide explanations for inhibition of receptor binding. The third could explain the binding enhancement seen with MAC 223 (Fig. 5c) if affinity was increased. Enhancement of binding is also seen with some monoclonal antibodies to ovine GH (Aston et al. 1987). Inhibition followed by recovery (MAC 218, 193 and 221, Fig. 5a) is not readily explained.

Enhancement of biological activity in vivo by $\mathrm{mAbs}$ has previously been demonstrated for a number of polypeptide hormones (Mockridge et al. 1998), including human GH (Holder et al. 1985), bovine GH (Aston et al. 1987) and human PL (Aston et al. 1986). At the doses used, both 
Table 3 Effects of monoclonal antibodies on the in vivo biological activity of ovine PL, tested in the pigeon crop sac bioassay

\begin{tabular}{|c|c|c|c|c|}
\hline & $\begin{array}{l}\text { Antigenic } \\
\text { determinant }\end{array}$ & $\begin{array}{l}\text { Dose of ovine PL } \\
(\mu \mathrm{g})\end{array}$ & $\begin{array}{l}\text { Mucosa, mean } \\
\text { weight difference } \\
(\mathrm{mg}) \pm \mathrm{SEM}\end{array}$ & $P$ value \\
\hline \multicolumn{5}{|c|}{$\mathrm{mAb}$} \\
\hline \multirow[t]{2}{*}{223} & 1 & 3 & $0 \cdot 2 \pm 1 \cdot 7$ & ns \\
\hline & & 5 & $0 \cdot 2 \pm 1 \cdot 4$ & ns \\
\hline \multirow[t]{2}{*}{218} & 2 & 3 & $3 \cdot 1 \pm 2 \cdot 6$ & ns \\
\hline & & 5 & $0 \cdot 9 \pm 2 \cdot 3$ & ns \\
\hline 220 & 2 & 5 & $3 \cdot 3 \pm 3 \cdot 3$ & $\mathrm{~ns}$ \\
\hline 193 & 3 & 3 & $33 \cdot 7 \pm 1 \cdot 7$ & $<0.001$ \\
\hline 224 & 4 & 5 & $1 \cdot 9 \pm 2.5$ & ns \\
\hline 222 & 5 & 5 & $8 \cdot 8 \pm 2 \cdot 3$ & ns \\
\hline \multirow[t]{2}{*}{221} & 6 & 3 & $10 \cdot 9 \pm 3 \cdot 4$ & $<0.05$ \\
\hline & & 5 & $10 \cdot 9 \pm 1 \cdot 8$ & $<0.01$ \\
\hline
\end{tabular}

MAC 193 (antigenic determinant 3) and MAC 221 (determinant 6) showed enhancing activity in the pigeon crop sac assay, the standard in vivo assay for prolactin action. The mechanism(s) underlying antibody-mediated enhancement remain imperfectly understood. However, of the various mechanisms proposed (Holder 1992), prolongation of hormone half-life is now thought to play a primary role (Mockridge et al. 1998). This mechanism is independent of any influence on receptor interaction.

\section{References}

Aston R, Holder AT, Preece M A \& Ivanyi J 1986 Potentiation of the somatogenic and lactogenic activity of human growth hormone with monoclonal antibodies. Journal of Endocrinology 110 381-388.

Aston R, Holder AT, Ivanyi J \& Bomford R 1987 Enhancement of bovine growth hormone activity in vivo by monoclonal antibodies. Molecular Immunology 24 143-150.

Bazin H 1982 Production of rat monoclonal antibodies with the LOU rat non secreting IR 983F myeloma cell line. In Protides of the Biological Fluids, 29th Colloqium 1982, pp 615-618. Ed H Peeters. Oxford \& New York: Pergammon Press.

Brier BH, Funk B, Surus A, Ambler GF, Wells CA, Waters MJ \& Gluckman PD 1994 Characterization of ovine growth hormone $(\mathrm{oGH})$ and ovine placental lactogen (oPL) binding to fetal and adult hepatic tissue in sheep: evidence that oGH and oPL interact with a common receptor. Endocrinology 135 919-928.

Cadman HF, Wallis M \& Ivanyi J 1982 The effects of monoclonal antibodies against human growth hormone on hormone receptor interactions. FEBS Letters 137 149-152.

Chan JSD, Robertson HA \& Friesen HG 1978 Maternal and fetal concentrations of ovine placental lactogen measured by radioimmunoassay. Endocrinology 102 1606-1613.

Colosi P, Thordarson G, Hellmiss R, Singh K, Forsyth IA, Gluckman P \& Wood WI 1989 Cloning and expression of ovine placental lactogen. Molecular Endocrinology 3 1462-1469.

Forsyth IA 1994 Comparative aspects of placental lactogens: structure and function. Experimental and Clinical Endocrinology 102 244-251.

Freemark M \& Comer M 1989 Purification of a distinct placental lactogen receptor, a new member of the growth hormone/prolactin receptor family. Journal of Clinical Investigation 83 883-889.

Galfrè G \& Milstein C 1981 Preparation of monoclonal antibodies: strategies and procedures. Methods in Enzymology 73 3-46.
Galfrè G, Milstein C \& Wright B 1979 Rat × rat hybrid myelomas and a monoclonal anti-Fd portion of mouse IgG. Nature 277 131-133.

Galosy SS, Gertler A, Elberg G \& Laird DM 1991 Distinct placental lactogen and prolactin (lactogen) receptors in bovine endometrium. Molecular and Cellular Endocrinology 78 229-239.

Gertler A, Grosclaude J, Strasburger CJ, Nir S \& Djiane J 1996 Real-time kinetic measurements of the interactions between lactogenic hormones and prolactin-receptor extracellular domains from several species support the model of hormone-induced transient receptor dimerization. Journal of Biological Chemistry 271 24482-24491.

Herman A, Helman D, Livnah O \& Gertler A 1999 Ruminant placental lactogens act as antagonisits to homologous growth hormone receptors and as agonisits to human or rabbit growth hormone receptors. Journal of Biological Chemistry 274 7631-7639.

Holder AT 1992 GH antibodies and somatic growth. In Regulation of Growth Hormone and Somatic Growth, pp 363-398. Ed LF De la Cruz. Amsterdam: Elsevier.

Holder AT, Aston R, Preece MA \& Ivanyi J 1985 Monoclonal antibody-mediated enhancement of growth hormone activity in vivo. Journal of Endocrinology 107 R9-R12.

Kelly PA, Tsushima T, Shiu RPC \& Friesen HG 1976 Lactogenic and growth hormone-like activities in pregnancy determined by radioreceptor assays. Endocrinology 99 765-774.

Krivi GG \& Rowold E 1986 Antigenic regions of bovine somatotropin as defined by monoclonal antibodies. Molecular Immunology $\mathbf{2 3}$ 1381-1389.

Mockridge JW, Holder AT \& Beattie J 1998 Enhancement of growth hormone $(\mathrm{GH})$ activity by antisera prepared against analogues of an epitope peptide defined by a GH-enhancing monoclonal antibody. Livestock Production Science 55 1-11.

Nicoll CS 1967 Bioassay of prolactin. Analysis of the pigeon crop-sac response to local prolactin injection by an objective and quantitative method. Endocrinology 80 641-655.

Notton BA, Fido RJ \& Galfrè G 1984 Monoclonal antibodies to a higher plant nitrate reductase: differential inhibition of enzyme activities. Planta 165 114-119.

Parke L \& Forsyth IA 1975 Assay of lactogenic hormones using receptors isolated from rabbit liver. Endocrine Research Communications 2 137-149.

Sakal E, Bignon C, Grosclaude J, Kantor A, Shapira R, Leibovitch H, Helman D, Nespoulous C, Shamay A, Rowlinson SW, Djiane J \& Gertler A 1997 Large-scale preparation and characterization of recombinant ovine placental lactogen. Journal of Endocrinology 152 $317-327$. 
Salacinski PRP, McLean C, Sykes JEC, Clement-Jones VV \& Lowry PJ 1981 Iodinations of proteins, glycoproteins and peptides using a solid-phase oxidising agent, 1,3,4,6-tetrachloro-3 $3,6 \alpha$ diphenylglycouril (iodogen). Analytical Biochemistry 117 136-146.

Strasburger CJ, Kostyo J, Vogel T, Barnard GJ \& Kohen F 1989 The antigenic epitopes of human growth hormone as mapped by monoclonal antibodies. Endocrinology 124 1548-1557.

Staten NR, Byatt JC \& Krivi GG 1993 Ligand-specific dimerization of the extracellular domain of the bovine growth hormone receptor. Journal of Biological Chemistry 268 18467-18473.

Thordarson G, McDowell GH, Smith SV, Iley S \& Forsyth IA 1987 Effects of continuous intravenous infusion of an ovine placental extract enriched in placental lactogen on plasma hormones, metabolites and metabolic biokinetics in non-pregnant sheep. Journal of Endocrinology 113 277-283.

Walker WH, Fitzpatrick SL, Barrera-Saldana HA, Resendez-Perez D \& Saunders GF 1991 The human placental lactogen genes: structure, function, evolution and transcriptional regulation. Endocrine Reviews 12 316-328.

Wells JA 1996 Binding in the growth hormone receptor complex. Proceedings of the National Academy of Sciences of the USA 93 1-6.

Winder SJ, Wheatley SD \& Forsyth IA 1993 Receptor binding of insulin-like growth factor-I to mammary microsomes from nonpregnant, pregnant and lactating sheep. Journal of Endocrinology 136 297-304.

Wooding FPB, Morgan G, Forsyth IA, Butcher G, Hutchings A, Billingsley SA \& Gluckman PD 1992 Light and electron microscopic studies of cellular localization of oPL with monoclonal and polyclonal antibodies. The Journal of Histochemistry and Cytochemistry 40 1001-1009.

Received 11 August 1999

Revised manuscript received 26 November 1999

Accepted 14 December 1999 